\title{
HEMOSTATIC EFFECT OF ETHANOLIC EXTRACT OF AGERATUM CONYZOIDES L TO STRAINS OF MICE MALE SWISS WEBSTER INDUCED WITH COMBINATION OF ASPIRIN, CLOPIDOGREL, AND ENOXAPARIN
}

\author{
YEDY PURWANDI SUKMAWAN ${ }^{1 *}$, HENDY SUHENDY² \\ ${ }^{1}$ Department of Pharmacology and Clinical Pharmacy, Program Study of Pharmacy, Institute of Health Science Bakti Tunas Husada, \\ Tasikmalaya, West Java, Indonesia. ${ }^{2}$ Department of Pharmacognosy, Program Study of Pharmacy, Institute of Health Science Bakti Tunas \\ Husada, Tasikmalaya, West Java, Indonesia. Email: yedipur@gmail.com
}

Received: 20 March 2017, Revised and Accepted: 16 April 2017

ABSTRACT

Objective: Bleeding complications are a common concern with the use of combination of antiagregations and anticoagulant agents especially on acute coronary syndrome treatment. In selected situations such as life-threatening, reversing may be desired, but no specific antidotum for the newer agents such as enoxaparin, fondaparinux, levirudin, bivalirudin, and argatroban. Ageratum conyzoides L is a medicinal plants that have a hemostatic effect. The objective of the study is to know the hemostatic effect of $A$. conyzoides $\mathrm{L}$ to induction of acetosal, clopidogrel, and enoxaparin.

Methods: A total of 20 mice are divided into five groups that are normal, negative, positive, Test I and II. There were no treatment for normal, induction of drugs combination for negative, induction of drugs combination and tranexamic acid for positive, induction of drugs combination and ethanolic extract of $A$. conyzoides L (100 mg/Kg BW) for Test I, induction of drugs combination and ethanolic extract of A. conyzoides L (250 mg/Kg BW) for Test II.

Results: The Test Groups I and II showed reversing of clotting time to normal baseline and shown a significant difference $(\mathrm{p}<0.05)$ compared with the negative group. In addition, the Test Groups I and II showed significant difference $(\mathrm{p}<0.05)$ of bleeding time compared with the negative group and the Test II (250 mg/Kg BW) shown reversing of bleeding time to normal baseline.

Conclusion: The hemostatic effect showed by ethanolic extract of $A$. conyzoides $\mathrm{L}$ to induction of combination acetosal, clopidogrel and enoxaparin are very valuable for reversing agent novel.

Keywords: Bleeding, Reversing, Hemostatic, Ageratum conyzoides L.

(C) 2017 The Authors. Published by Innovare Academic Sciences Pvt Ltd. This is an open access article under the CC BY license (http://creativecommons. org/licenses/by/4. 0/) DOI: http://dx.doi.org/10.22159/ajpcr.2017.v10i7.18573

\section{INTRODUCTION}

Cardiovascular disease is the leading cause of death in the world in 2012 followed by cancer, respiratory disease, and diabetes mellitus [1]. In Indonesia, ischemic heart disease is the second cause of death in 2012 after stroke [1]. Acute coronary syndrome included as ischemic heart disease. Acute coronary syndrome be marked by atherosclerosis on the coronary artery of the heart [2]. Development of atherosclerosis takes 10-15 years and related with high of blood fat level (cholesterol, triglyceride, and low-density lipoprotein) and be accompanied by inflammation reaction $[2,3]$.

Pharmacotherapy handling in patients with coronary artery disease involves the use of bloodthinning drugs such as aspirin, clopidogrel, and an anticoagulant (enoxaparin, fondaparinux, bivalirudin, and unfractionated heparin) or in combination [3-5]. The use of these drugs has been shown to reduce morbidity and mortality [6,7]. Cilostazol may administrate with the combination of another blood thinning drugs for acute coronary syndrome [8,9]. However, the use of blood thinning drugs can increase the risk of bleeding and life-threatening of patients $[10,11]$. In selected situations, reversing this effect may be desired. Bleeding incidents on acute coronary syndrome caused by enoxaparin administration reach $4.7 \%$ [12].

Until now, there is not an antidote, especially to medications such as blood thinners newest class of low molecular weight heparin (LMWH) (enoxaparin), fondaparinux, levirudin, bivalirudin, and argatroban, including antiplatelet such as clopidogrel and aspirin. Protamine as specific antidotes for unfractionated heparin only able to restore
$60 \%$ of coagulation in the class of LMWH (enoxaparin), and provide a very small activity in the fondaparinux $[13,14]$. As for aspirin and clopidogrel, reversal treatment only through platelet transfusions [11].

Ageratum conyzoides $\mathrm{L}$ is a traditional herbal medicines and has been known to have a hemostatic effect and has proven preclinical either in the form of decoction or in the form of the extract $[15,16]$. In addition, this plant has much use in medication such as ophthalmia, colic, ulcers, wound healing, antipyretic, infectious disease, headache, dyspnea, antiasthmatic, antispasmodic, uterine trouble, fever, measles, snake bites, pain associated, and diarrhea $[15,17]$. Therefore, this work was undertaken to investigate the possible hemostatic effects of the ethanolic extract of $A$. conyzoides $\mathrm{L}$ to male mice with induction of combination acetosal, clopidogrel, and enoxaparin.

\section{METHODS}

\section{Animal}

A total of 20 Swiss Webster strains of male mice weighing between 20 and $30 \mathrm{~g}$ were used. The mice were divided into five groups of four animals each group. The mice were purchased from School of Life Science, Institute Teknologi Bandung, Indonesia. The mice were housed in wire mesh cages under standard conditions (temperature, $25-30^{\circ} \mathrm{C}, 12 \mathrm{hrs}$ lights, and 12 hrs dark cycles) and allowed to acclimatize for 5 days. The mice were fed with standard pellets diet, and water was given ad libitum.

Chemical

Acetosal (PT. Darya Varia), clopidogrel (PT. Kalbe Pharma), enoxaparin (PT. Sanofi), ammonium hydroxide, chloroform, hydrochloric acid, 
dragendorff dan mayer reagents, magnesium, amyl alcohol, gelatin, ferrous (III) chloride, potassium hydroxide, diethyl ether, vanillin, $\mathrm{H}_{2} \mathrm{SO}_{4}$, acetic acid, carboxymethylcellulose-Na (Merck), and ethanol 96\% (PT. Brataco).

\section{Preparation of plant extract}

Fresh leaves of $A$. conyzoides $\mathrm{L}$ were collected from Rajapolah district, Indonesia. Plant identification and authentication were done by the Herbarium of School of Life Sciences, Institute Teknologi Bandung, Indonesia. The leaves were washed in tap water and shade-dried after which they were reduced into a fine powder by grinding and macerated for $72 \mathrm{hrs}$ in ethanol $(95 \% \mathrm{v} / \mathrm{v})$ at room temperature. It was subsequently filtered with Whatman filter paper to separate the filtrate from the residue. The filtrate was subsequently concentrated using a rotary vacuum evaporator to obtain the solid extract. The solid extract was then stored in capped bottles in a refrigerator at $4^{\circ} \mathrm{C}$ until required.

\section{Phytochemical screening}

Phytochemical screening was conducted on the inspection of secondary metabolites such as alkaloid, flavonoid, saponin, tannin, polyphenol, sesquiterpene, monoterpene, steroid, triterpenoid, and quinone. The phytochemical screening was conducted complied to Farnsworth methods (1966) [18].

\section{Characterization of plants}

Simplicia characterization examination was conducted on the examination of moisture content, ash content, acid insoluble ash, water soluble extract, and ethanol soluble extract. The characterization was conducted complied to Department of Health of Indonesia (2000) [19].

\section{Experimental procedure}

The study was conducted on five groups of male mice. Each group contained four mice and was placed in a different cage for proper identification. The control group was not given any treatment, negative group was given combination of acetosal $(0.26 \mathrm{mg} / 20 \mathrm{~g} \mathrm{BW}$ mice/day), clopidogrel $(0.2 \mathrm{mg} / 20 \mathrm{~g} \mathrm{BW}$ mice/day), and enoxaparin $(0.02 \mathrm{mg} / 20 \mathrm{~g}$ BW mice in two divided dose/day) for 3 days and then 60 minute later was given placebo (CMC 1\%), positive group was given combination of acetosal $(0.26 \mathrm{mg} / 20 \mathrm{~g} \mathrm{BW}$ mice/day), clopidogrel $(0.2 \mathrm{mg} / 20 \mathrm{~g} \mathrm{BW}$ mice/day), and enoxaparin $(0.02 \mathrm{mg} / 20 \mathrm{~g} \mathrm{BW}$ mice in two divided dose/day) for 3 days and then 60 minute later was given tranexamic acid (1.3 mg/20 g BW of mice), while Test Groups I and II were given combination of acetosal $(0.26 \mathrm{mg} / 20 \mathrm{~g}$ BW mice/day), clopidogrel ( $0.2 \mathrm{mg} / 20 \mathrm{~g}$ BW mice/day), and enoxaparin $(0.02 \mathrm{mg} / 20 \mathrm{~g}$ BW mice in two divided dose/day) for 3 days and then 60 minute later was given different concentrations (100 and $250 \mathrm{mg} / \mathrm{kg}$ ) of ethanolic extract of A. conyzoides L orally. All procedures involving the use of animals in this study complied to the guidelines for the Care and Use of Laboratory Animals [20].

\section{Determination of bleeding time}

The determination of bleeding time using the modified Duke [21]. The tail of each animal from each group carried out disinfection using $70 \%$ alcohol. Then, the tail end of the cut using a scalpel (lancet) disposable and a stopwatch started as soon as possible when bleeding occurs. The tailpiece then swabbed using filter paper every 15 seconds until the filter paper no longer stained with blood. Bleeding time is determined when the blood stops flowing from the cut tail.

\section{Determination of clotting time}

Determination of clotting time using the procedure described Cole [22]. The tail of each animal from each group carried out disinfection using $70 \%$ alcohol. Then, cut using a scalpel (lancet) disposable. The tail of each animal immediately put into a glass test tube which had previously been heated and maintained in a temperature of $37^{\circ} \mathrm{C}$, after the tube quickly placed back in the water bath with a temperature of $37^{\circ} \mathrm{C}$ so as to resemble the body temperature. The stopwatch is turned on as soon as possible when the blood is inserted in the glass tube test to determine clotting time that is characterized by the formation of blood which resembles gelatin.

\section{Statistical analysis}

All data were presented as mean \pm SE. One-way ANOVA was used to analyze the data, followed by a post-hoc test (least significance different). The results were considered significant at $(\mathrm{p}<0.05)$.

\section{RESULTS}

\section{Phytochemical screening}

The phytochemical screening of $A$. conyzoides $L$ shown positive results for tannin, polyphenol, steroid, triterpenoid, quinone, and flavonoid. In addition, it was showed negative results for alkaloid, saponin, sesquiterpene, and monoterpene as showed on Table 1.

\section{Characterization of plants}

The moisture contents of $A$. conyzoides were $9 \pm 4.24 \%$, while of total ash, acid insoluble ash, ethanol soluble extract, and water soluble extract are $13.75 \pm 1.56 \%, 4.09 \pm 1.15 \%, 5.83 \pm 0.45 \%$, and $2.33 \pm 0.57 \%$, respectively, as showed on Table 2 .

\section{Table 1: Result of phytochemical screening of $A$. conyzoides $\mathrm{L}$}

\begin{tabular}{ll}
\hline Secondary metabolite & Results \\
\hline Alkaloid & - \\
Saponin & - \\
Sesquiterpene and monoterpene & - \\
Tannin and polyphenol & + \\
Steroid and triterpenoid & + \\
Quinone & + \\
Flavonoid & + \\
\hline
\end{tabular}

A. conyzoides: Ageratum conyzoides

Table 2: Result of characterization of $A$. conyzoides $\mathrm{L}$

\begin{tabular}{ll}
\hline Characteristic & Results (\%) \\
\hline Moisture contents & $9.00 \pm 4.24$ \\
Total ash & $13.75 \pm 1.56$ \\
Acid insoluble ash & $4.09 \pm 1.15$ \\
Rendement & 26.99 \\
Water soluble extract & $5.83 \pm 0.45$ \\
Ethanol soluble extract & $2.33 \pm 0.57$ \\
\hline
\end{tabular}

A. conyzoides: Ageratum conyzoides

Table 3: Results of bleeding time

\begin{tabular}{ll}
\hline Group & $\begin{array}{l}\text { Average of } \\
\text { bleeding time (s) }\end{array}$ \\
\hline Normal & $2904.75 \pm 74.28^{*}$ \\
Negative & $4567.25 \pm 117.43$ \\
Positive (tranexamic acid $1.3 \mathrm{mg} / 20 \mathrm{~g} \mathrm{BW})$ & $4162.75 \pm 122.67^{*}$ \\
Test I (extract $A$. conyzoides L $100 \mathrm{mg} / \mathrm{Kg} \mathrm{BW})$ & $3720.25 \pm 97.19^{*}$ \\
Test II (extract $A$. conyzoides L $250 \mathrm{mg} / \mathrm{Kg} \mathrm{BW})$ & $3077.00 \pm 139.21^{*}$ \\
\hline
\end{tabular}

Results are expressed as mean \pm SD *explain significant difference compared with the negative control, $A$. conyzoides: Ageratum conyzoides

Table 4: Results of clotting time

\begin{tabular}{ll}
\hline Group & $\begin{array}{l}\text { Average of } \\
\text { clotting time (s) }\end{array}$ \\
\hline Normal & $90.5 \pm 5.81$ \\
Negative & $105 \pm 12.06$ \\
Positive (tranexamic acid $1.3 \mathrm{mg} / 20 \mathrm{~g} \mathrm{BW})$ & $101.5 \pm 16.97$ \\
Test I (extract $A$. conyzoides L $100 \mathrm{mg} / \mathrm{Kg} \mathrm{BW})$ & $87.25 \pm 4.96^{*}$ \\
Test II (extract $A$. conyzoides L $250 \mathrm{mg} / \mathrm{Kg} \mathrm{BW})$ & $83.25 \pm 3.49^{*}$ \\
\hline
\end{tabular}

Results are expressed as mean \pm SD *explain significant difference compared with the negative control 


\section{Bleeding time}

The result of the timing of the bleeding state that induction using a combination of aspirin, clopidogrel, and enoxaparin provide increased time bleeding significantly from the negative control group $(p<0.05)$ when compared to the normal group. Meanwhile, the positive control group, Test I and II provides a decrease in bleeding time was significantly $(\mathrm{p}<0.05)$ when compared to the negative control group as showed on Table 3.

\section{Clotting time}

The results of the determination of clotting time stating that induction using a combination of aspirin, clopidogrel, and enoxaparin provide increased time clotting time although not significant from the negative control group ( $p>0.05)$ when compared to the normal group. Group Test I and II provides a reduction in clotting time was significantly $(p<0.05)$ when compared to the negative control group. While the positive control group did not give a significant difference of clotting time reduction ( $p>0.05$ ) when compared to the negative control as showed on Table 4.

\section{DISCUSSION}

The objective of characterization simplicia of $A$. conyzoides $\mathrm{L}$ is to meet the requirements set, known quality and ensure specific characteristics simplicia used for testing [23]. Differences in characteristics can provide different results on their activities. The results of water content are $9 \pm 4.24 \%$. The value is clear that the water content of crude drugs used is in accordance with the requirements set which must be $<10 \%$. This is because the high levels of water can reduce the quality simplicia and lead to the growth of mold or bacteria. The results of acid insoluble ash are $4.09 \pm 1.15 \%$, and it is showed the contents of sand and another components such as silica. While phytochemical screening conducted to determine the content of secondary metabolites contained in A. conyzoides $\mathrm{L}$ and the results of the screening showed positive of flavonoids and tannin. Both of these are secondary metabolites that provide hemostatic efficacy [24-26]. Tannin is a compound that has a physiological effect on the plant itself, which is to stop the bleeding when there is damage to the plant tissues [24].

In the determination $t$ of bleeding time, the negative control group was significantly different $(\mathrm{p}<0.05)$ when compared to the normal group. The increase in bleeding time caused by the negative control group induction of a combination of aspirin, clopidogrel, and enoxaparin. Aspirin and clopidogrel are a compound that can inhibit platelet aggregation through the inhibition to the formation of thromboxane A2 and through inhibition at P2Y12 receptor so that the molecule of adenosine diphosphate released from platelets that have been activated cannot bind to its receptor, resulting in down-regulation of adenylyl cyclase, inactivation complex GPIIb/IIIa and inhibit binding of fibrinogen $[3,27,28]$. As for enoxaparin is a group of LMWH to prevent the occurrence of coagulation through the inactivation on factor Xa and also have a small effect on factor IIa (Thrombin) [29]. In the Test Groups I and II trials reduction of the bleeding time were significant $(p<0.05)$ than those in the negative. In addition, the Test Groups I and II trials also provide reduction effect significant difference $(\mathrm{p}<0.05)$ when compared to the positive control group. In the Test Group II, the effect of decreasing the bleeding time nearing bleeding time value in the normal group $(p>0.05)$. In the positive control group, provides no significant difference $(p<0.05)$ to the negative control group and did not give a reduction in bleeding to normal levels as the Test Group II, marked the significant difference with the normal group $(p<0.05)$. This indicates that the Test Group II can restore an increased bleeding time induced by the combination of aspirin, clopidogrel, and enoxaparin to a normal bleeding time (baseline). The ability of ethanol extract of A. conyzoides L in reducing the bleeding time may through increased concentration of platelets, platelet activation, and extrinsic factors (factor VII and X) since the determination of bleeding time induced by anti aggregation platelets (aspirin, clopidogrel) and anticoagulants (enoxaparin) previously as well as the bleeding time to assessment of platelet function. In addition, the procedure used of this determination through cut the tail resulting tissue damage of the experimental animals, thus activating the extrinsic pathway through the release of tissue factors [30].

In the determination of clotting time showed increased of clotting time in the negative control group when compared to the normal group although not significantly different. The increase in clotting time caused by the negative control group induction of a combination of aspirin, clopidogrel, and enoxaparin. Meanwhile, in the Test Groups I and II trials reduction of clotting time were significant $(\mathrm{p}<0.05)$ when compared to the negative group. The Test Groups I and II trials can reduce clotting time until the normal clotting time (baseline). While the positive control group did not give a time reduction of clotting time ( $p>0.05$ ) when compared to the negative control. Clotting time test is a qualitative test to ensure the involvement of intrinsic factor [15,31], so the reduction of clotting time until reach the normal time may be attributable to an increase in one or several intrinsic factors (I, II, V, VIII, IX, X, XI, XII) [16].

\section{CONCLUSION}

Based on the research that has been conducted, it can be concluded that the ethanolic extract of leaves babadotan (A. conyzoides L) has a hemostatic effect to the induction of combination of aspirin, clopidogrel, and enoxaparin. The hemostatic effect of the extract may through activate the extrinsic and intrinsic pathways. The extract of A. conyzoides $\mathrm{L}$ can be used as an antidote candidate to internal bleeding caused by a combination of aspirin, clopidogrel, and enoxaparin in the management of acute coronary syndrome.

\section{ACKNOWLEDGMENT}

Authors are thankful to Dr. Ruswanto, chief of research centers and community service, Institute of Health Science Bakti Tunas Husada, for his kind support.

\section{REFERENCES}

1. Available from: http://www.who.int/gho/ncd/mortality_morbidity/en/.

2. Boudi. Coronary Artery Atherosclerosis. Available from: http://www. emedicine.medscape.com/article/153647-overview\#a1.2016. [Last accessed on 2017 Mar 14].

3. Dipiro JT, Talbert RL, Yee GC, Matzke GR, Wells BG, Posey ML. Pharmacotherapy "A Patophysiologic Approach. New York: Mc Graw Hill; 2008

4. American Heart Association. Heart Disease and Stroke Statistic. Update. Dallas, TX: American Heart Association; 2007.

5. Alam S, Naqvi SB, Ahmed M. Drug utilization and economic impact of anticoagulants in unstable angina/non-St. elevation myocardial infarction in Karachi. Int J Pharm Pharm Sci 2015;7(3):183-5.

6. Peterson ED, Roe MT, Mulgund J, DeLong ER, Lytle BL, Brindis $\mathrm{RG}$, et al. Association between hospital process performance and outcomes among patients with acute coronary syndromes. JAMA 2006;295:1912-20

7. Eagle KA, Montoye CK, Riba AL, DeFranco AC, Parrish R, Skorcz S, et al. Guideline-based standardized care is associated with substantially lower mortality in medicare patients with acute myocardial infarction: The American college of cardiology's guidelines applied in practice (GAP) projects in Michigan. J Am Coll Cardiol 2005;46(7):1242-8.

8. Hu T, Ma H, Li H, Ren J. Efficacy of cilostazol in patients with acute coronary syndrome after percutaneous coronary intervention. Am J Ther 2013;20(2):151-3.

9. Sukmawan YP. Cilostazol did not induce any adverse reactions in coronary arterial disease (non-st elevation myocardial infarction) with congestive heart failure comorbidity: A case report. Asian J Pharm Clin Res 2017;10(1):1-2.

10. Oldgren J, Wernroth L, Stenestrand U; RIKS-HIA registry, Sweden. Fibrinolytic therapy and bleeding complications: Risk predictors from RIKS-HIA. Heart 2010;96(18): 1451-7.

11. Makris M, Van Veen JJ, Tait CR, Mumford AD, Laffan M; British Committee for Standards in Haematology. Guideline on the management of bleeding in patients on antithrombotic agents. $\mathrm{Br} \mathrm{J}$ Haematol 2013;160(1):35-46.

12. Petersen JL, Mahaffey KW, Hasselblad V, Antman EM, Cohen M, Goodman SG, et al. Efficacy and bleeding complications among 
patients randomized to enoxaparin or unfractionatedheparin for antithrombin therapy in non-Stsegment elevation acute coronary syndromes: A systematic overview. JAMA 2004;292(1):89-96.

13. Warkentin TE, Crowther MA. Reversing anticoagulants both old and new. Can J Anaesth 2002;49:S11-25.

14. Van Veen JJ, Maclean RM, Hampton KK, Laidlaw S, Kitchen S, Toth P, et al. Protamine reversal of low molecular weight heparin: Clinically effective? Blood Coagul Fibrinolysis 2011;22(7):565-70.

15. Kamboj A, Saluja AK. Ageratum conyzoides L.: A review on its phytochemical and pharmacological profile. Int $\mathrm{J}$ Green Pharm 2008;2(2):59-68

16. Bamidele O, Akinnuga AM, Anyakudo MM, Ojo OA, Ojo GB, Olorunfemi JO, et al. Haemostatic effect of methanolic leaf extract of Ageratum conyzoides in albino mice. J Med Plants Res 2010;4(20):2075-9.

17. A Diallo B, Batomayenab LE, Povic KE, Gadegbekuc K, Aklikokouc E, Creppyd M, et al. Fetal toxicity of hydroalcoholic extract of Ageratum conyzoides L. leaves (Asteraceae) in rats. Int J Pharm Pharm Sci 2015;7(8):264-6.

18. Farnsworth NR. Biological and phytochemical screening of plants. J Pharm Sci 1966;55(3):225-76.

19. Depkes RI. Parameter Standar Umum Extract Tumbuhan. Obat, Jakarta: Depkes RI; 2000.

20. Vogel HG, editor. Drugs Discovery and Evaluation Pharmacological Assays. New York: Springer; 2008.

21. Ochei J, Kolhatkar A. Medical Laboratory Science. Theory and Practice. New Delhi; Tata Mcgraw-Hill Publishing Company Limited; 2000 .
22. Cole MR. Evaluation of Hemostasis and Coagulation Disorders in Veterinary Laboratory Medicine. Philadelphia: W.B. Saunders; 1987. p. 43-9.

23. Isnawati A, Alleganti S, Raini M, Nikmah B. Karakterisasi Simplisia dan Ekstrak Daun Strobilanthus Crispus. Vol. XIV. No. 2. Jakarta: Media Litbang Kesehatan; 2004.

24. Okoli CO, Akah PA, Okoli AS. Potentials of leaves of Aspilia africana (Compositae) in wound care: An experimental evaluation. BMC Complement Altern Med 2007;7:24.

25. Galati EM, Miceli N, Taviano MF, Sanogo R, Raneri E. Antiinflammatory and antioxidant activity of Ageratum conyzoides. Pharm Bio 2001;39(5):336-9.

26. Chung KT, Wong TY, Wei CI, Huang YW, Lin Y. Tannins and human health: A review. Crit Rev Food Sci Nutr 1998;38(6):421-64.

27. Alquwaizani M, Buckley L, Adams C, Fanikos J. Anticoagulants: A review of the pharmacology, dosing, and complications. Curr Emerg Hosp Med Rep 2013;1(2):83-97.

28. Savi P, Nurden P, Nurden AT, Levy-Toledano S, Herbert JM. Clopidogrel: A review of its mechanism of action. Platelets 1998;9(3-4):251-5.

29. Brian A, Robin C, Michael E, Joseph GB, Pamela J, Wayne K, et al. Koda-Kimble and Young's Applied Therapeutics: The Clinical Use of Drugs. $10^{\text {th }}$ ed. USA: Lippincott Williams and Wilkins; 2013.

30. Wajima T, Isbister GK, Duffull SB. A comprehensive model for the humoral coagulation network in humans. Clin Pharmacol Ther 2009;86(3):290-8.

31. Dapper DV, Achinike PN, Gwotmut MD. Effects of Aloe vera (gel) on clotting time, prothrombin time and plasma fibrinogen concentration in albino Wistar rats. Port Harcourt Med J 2007;2(1):56-60. 